
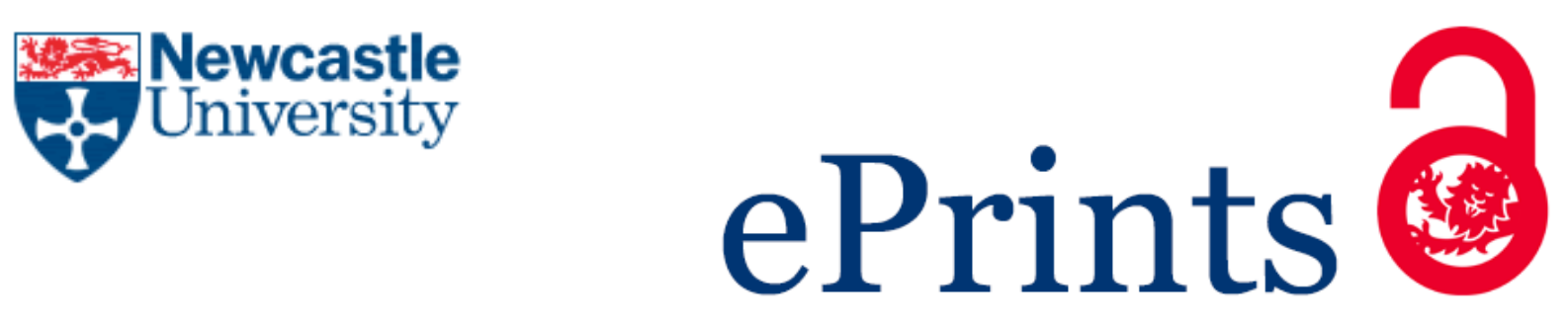

Parry SN. The influence of neoliberal economics on small business accounting research: a critical evaluation of agendas and methodologies. International Small Business Journal 2015. DOI: 10.1177/0266242615600508

Copyright:

Copyright @ 2015 by SAGE Publications

DOI link to article:

http://dx.doi.org/10.1177/0266242615600508.

Date deposited:

$08 / 09 / 2015$

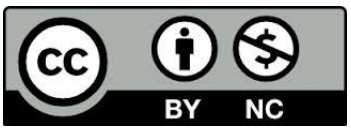

This work is licensed under a Creative Commons Attribution-NonCommercial 3.0 Unported License 


\title{
The influence of neoliberal economics on small business accounting research: a critical evaluation of agendas and methodologies
}

\author{
Simon N Parry \\ Newcastle University Business School \\ 5 Barrack Road, Newcastle upon Tyne, NE1 4SE \\ Tel: +44 (0) 1912081500 \\ Email: simon.parry@ncl.ac.uk
}

\begin{abstract}
This paper contributes to current debates on agendas and methodologies in small business research by critiquing small business accounting research paradigms within the context of contemporary neoliberal economic policy. Research published in leading academic journals over the last 30 years is critically examined and it is posited that a hegemonic neoliberal economic discourse of entrepreneurship has resulted in the dominance of a narrow research focus and a restricted range of research agendas. The paper argues that there is both an economic and an epistemological rationale for more research which focuses on the broader social and political context of accounting within small businesses, rather than a narrow focus on accounting's role in business growth. In particular, there is a need for more research which focuses on accounting within non-growth-oriented "lifestyle" businesses. The question of appropriate methodology for future research is raised. The limitations of a predominantly quantitative, survey-based and normative approach are discussed and the potential benefits of alternative methodologies are explored.
\end{abstract}


The influence of neoliberal economics on small business accounting research: a critical evaluation of agendas and methodologies

\section{Introduction}

This article contributes to an ongoing debate on agendas and methodologies in small business research (Watkins, 1995; Gibb, 2000a; Curran and Blackburn, 2001; Blackburn and Smallbone, 2008; Blackburn and Kovalainen 2009; Volery and Mazzarol, 2015) and responds to the criticism that small business and entrepreneurship scholarship is insufficiently scrutinized from a critical standpoint (Ogbor, 2000; Garud, Hardy and Maguire, 2007; Khan, Munir and Willmott, 2007). A critical review of small business accounting research (SBAR) published over the last 30 years is presented in order to analyse its contribution but also, to suggest directions for future research. It is argued that SBAR has struggled to find its place in the research world which contrasts strongly with developments within the wider field of small business research during this same period. In particular, SBAR has been heavily influenced by stakeholders given their command of funding initiatives, leading to a narrow focus on the interests of policy-makers and practitioners so informs research concerned with policy and/or practice development rather than theory building.

Whereas academics often see themselves as morally neutral technicians, we argue that SBAR is not neutral; rather, it has been both shaped by and in turn contributed to a neoliberal economic ideology. Aside from criticism of this ideology, it is argued that the result has been a constraint on both research agendas and methodologies which has constrained the development and potential contribution of SBAR. This critique raises fundamental questions regarding the role and purpose of SBAR; thus, we examine the question of what knowledge we should be trying to obtain from a SBAR endeavour, suggesting that important areas have been ignored. The article therefore, seeks to stimulate debate on agendas and methodologies specifically within SBAR and to promote a broadening of perspectives and more self-reflexive approach to such research.

The neoliberal economic agenda, which has provided the foundation for economic policy in the developed Western economies and increasingly, upon a global basis has redefined the discourse of business, giving emphasis to innovation, creativity, flexibility and the ability to take advantage of opportunities (Short, Ketchen, Shook and Ireland, 2010). Neoliberalism proposes that prosperity is better achieved by an economy that favours larger numbers of small firms rather than a small number of large firms, that is controlled by market forces rather than governments or trade unions and that allows free international competition rather than protected national markets (Dannreuther, 2009). This agenda privileges personal freedom and individual liberty over state control, advocating reduced government control and a decentralisation that has positioned small businesses and entrepreneurship as critical within global markets that are increasingly unpredictable and competitive (Howard,1990; 
The influence of neoliberal economics on small business accounting research: a critical evaluation of agendas and methodologies

Lumpkin and Dess, 1996). This in turn, has produced a hegemonic discourse of entrepreneurship as a significant constituent of economic contribution (Costa and Saraiva 2012) and small businesses as the cornerstone of economic growth (Audretsch and Keilbach, 2006). Successive global governments have turned to small businesses as the providers of economic growth (Cunningham 2011), increased income (Parker, 2006), employment (Varum and Rocha 2013) and innovation (González-Loureiro and Pita-Castelo 2012).

A contributing factor to the focus on growth has been the manner in which many academics have defined entrepreneurship in terms of growth. Many have differentiated entrepreneurs from small business owners (c.f. Wagener, Gorgievski and Rijsdijk, 2010; Owens, Kirwan, Lounsbury, Levy and Gibson, 2013) or identified an entrepreneurial orientation as opposed to a small business orientation (Runyan, Droge and Swinney, 2008; Lechner and Gudmundsson, 2014; Wales, Wiklund and McKelvie, 2015), with firm growth being accepted as the indicator of entrepreneurship (Moreno and Casillas, 2008; Koryak, Mole, Lockett, Hayton, Ucbasaran and Hodgkinson, 2015). However, others have defined the entrepreneur as the founder of a new business (Fraser, Bhaumik and Wright, 2015), such that all new small businesses fall under the umbrella of entrepreneurship. This conflation of terminology has resulted in an 'ideal' type of small business and the notion that those who do not measure up to this ideal are somehow lacking in a way that can be resolved with the right support or intervention. This has led to substantial government intervention and public expenditure to stimulate and support the creation of new small businesses and to encourage small business growth (Storey, 2006). The attitude of policymakers has also created a setting for research that assumes more entrepreneurial activity is universally beneficial (Nightingale \& Coad, 2014).

This article amalgamates these factors to inform the following research question - 'to what extent has neoliberal economic discourse shaped SBAR over the last 30 years?' To explore this question, the discussion is structured as follows: First, the methodology employed to develop a systematic literature review is outlined, the resultant categories are then described,

\section{Methodology}

This article is based upon a systematic literature review; an approach recognised as expedient in making sense of what a collection of studies are saying, and revealing assumptions underpinning that body of research (Transfield, Denyer and Smart, 2003; 
The influence of neoliberal economics on small business accounting research: a critical evaluation of agendas and methodologies

Thorpe, Holt, MacPherson and Pittaway, 2005). A three-stage approach is adopted which emphasises transparency, reproducibility and a clear audit trail. The following sections explain more fully these three steps of planning the review; conducting the review; and reporting the review.

\section{Stage One: Planning the review}

The purpose of this study is to identify the research interests and the underlying discourses of published SBAR. The parameters of the review were therefore, largely demarcated by this focus. However, there is no explicitly delineated area of labelled 'small business accounting research'. Rather, it is a sub-set of the wider fields of entrepreneurial and small business research and, occasionally, of mainstream accounting research. This means that research which does look at accounting in small businesses is diverse in its interests, methodologies and publication outlets. Whilst selecting a single journal for a review has the benefit of revealing the ongoing debates therein (Perren and Jennings, 2012), there is the drawback that individual journals have specific interests and methodological preferences. Therefore, given the diversity of interests identified above, drawing a sample from a wide range of sources in order to reflect the agendas and methodologies found across the field offers a more robust approach. A number of small business accounting studies have been sponsored and published by professional accounting bodies and others are reported in books or book chapters. Whereas these studies were identified and considered, the sample was restricted to articles published in ranked international academic journals ${ }^{1}$, to ensure that only peer-reviewed academic work was included. The timescale chosen for the review was the 30 year period from 1983 to 2013, reflecting the period during which neoliberal economic philosophy has been most prevalent.

\section{Stage Two: Conducting the review}

The review was conducted using a two-step process. First, relevant studies were identified through systematic searches of three academic databases: Business Source Premier, Web of Knowledge and Google Scholar. Second, both a forward and backward reference search was conducted. The database searches covered full text rather than just title and abstract, and made full use of Boolean logic and wild cards to ensure that variations and derivatives of key words were identified. The basic search terms used were: account* OR financ*, linked with (AND) 'small business'; 'SME'; 'micro business'; 'small firm'; 'micro firm'. These search terms reflect the discussion above regarding terminology used in academic literature. The searches picked up nearly 3,000 academic articles, as many had minor use of one or more

\footnotetext{
${ }^{1}$ All journals are included in the UK ABS and/or the Australian ABDC ranking list.
} 
The influence of neoliberal economics on small business accounting research: a critical evaluation of agendas and methodologies

of the search terms. The abstract (and if necessary the body) of every article identified was reviewed to evaluate its relevance to the study. The review took a broad perspective on what constitutes accounting practices and activities, including studies looking at management accounting and control, financial reporting, statutory accounting activities such as VAT accounting, financial planning and the use of financial information in decision making. An article was deemed to be relevant if it was concerned with the production or use of accounting information within a small business. The criteria for inclusion included a concern with:

- accounting record keeping

- accounting information usage in decision making

- accounting system development

- financial reporting

This selection process produced a sample of 108 academic studies from 27 different academic journals. (See table 1). The studies have a broad international mix, covering small businesses in the UK, the US and Canada, Scandinavia, Europe, Asia and Australian. The scope of articles includes some which are not looking explicitly or exclusively at matters of accounting and it was found that SBAR is by no means a homogeneous endeavour. It is underpinned by a diversity of knowledge interests including the role of business advisors, the information needs of owner-managers, methods of financial decision making, the needs of finance providers, the impact of regulation, and business success factors.

\section{INSERT TABLE 1 (Frequency of papers by Journal Source)}

\section{Stage Three: Reporting the review}

As suggested by Transfield et al (2003), the review is presented as a thematic analysis. The analysis of the sample consisted of three phases as presented in Figure 1. First, the research interests of each study were identified and grouped into categories (open coding). The primary focus of this analysis was the (taken for granted or explicit) assumptions that underpinned the research interest. All the articles selected were entered into an Excel spreadsheet, using separate cells to code information such as study topic, methodology, theoretical underpinning and key findings. For this first stage of analysis in-vivo codes were used whenever possible to capture the essence of that category (Strauss and Corbin, 1998), otherwise a simple descriptive phrase was used (Gioia, Price, Hamilton and Thomas, 2010). Figure 1, column 1 presents illustrative quotes or summations from selected individual articles as representative of the first-order categories (the \#tag denoting the paper number from the sample). The second stage of analysis (Figure 1, column 2) consisted of axial 
coding (Strauss and Corbin, 1998), which involved searching for relationships between the first order categories and assembling them into higher-order themes. Similar themes were gathered into the overarching dimensions that make up the framework of the discussion set out below. This analysis was undertaken using coding cells within the Excel spreadsheet, which enabled sorting and filtering of the sample for comparison between concepts and quick reference back to the relevant articles. It also enabled the grouping of articles into fewer categories and themes, as well as the identification of articles that fitted into more than one theme or that needed to be broken down into more fine-grained categorisation. The final stage of analysis involved identifying and classifying the underlying discourses of the studies (Figure 1, column 3). This was done with reference to the exposition of neoliberal economic discourse set out in the previous section and each article was classified as presenting either a 'dominant' or 'counter' discourse in relation to the higher-order theme. The development and refinement of coding continued until all articles had been settled within the emerging framework.

\section{INSERT FIGURE 1 (Data Structure)}

The result of this analysis was a coding of the literature into four higher-order themes, as presented in Figure 1, column 2. The first area of interest is accounting information usage and how this can contribute to, or hinder, small business growth. A second area being how accounting information is used and the financial competencies within small businesses. The remaining two themes were the use and provision of accounting information and services by business advisors and the impact of regulative burden on small businesses. Each of these four categories is examined in more detail below.

\section{Accounting information and growth}

The first category of studies can be characterised by attempts to establish a positive link between small business growth and the use of accounting information. Small business accounting, or a lack of it, has been identified as a barrier to growth (Reid, 1995; Leonidou, 2004) or as a direct factor in the failure of the business (Ezzamel and Bourn, 1990; Hall and Young, 1991; Pompe and Bilderbeek, 2004). Studies concerned with accounting and growth fall into three sub-groups: the first consider the provision and use of financial accounting in small businesses; the second, internal management accounting procedures; the third link accounting with growth models and stages of small business development. 
The influence of neoliberal economics on small business accounting research: a critical evaluation of agendas and methodologies

The group of studies looking at financial accounting have been concerned with identifying what financial information is used in the management of small businesses (Marriott and Marriott, 2000; Collis and Jarvis, 2002; Collis, Jarvis and Skerratt, 2004). This group includes those that explore the use of formal financial analysis such as financial ratios (Holmes and Nichols, 1989; McMahon and Davies, 1991) The main interest of these being to establish a correlation between the use of financial information and the success of the business (c.f. Thomas and Evanson, 1987; Romano and Ratnatunga, 1994; McMahon, 2001; Pompe and Bilderbeek, 2004).

The dominant discourse within these studies conceptualises success as economic at the organisational level. This economic conceptualisation of success also defines, by implication, a lack of success. The neoliberal discourse of globalisation, deregulation, marketization and privatisation positions the successful entrepreneur as one who seizes the entrepreneurial opportunities afforded by such an agenda. Several studies adopt this discourse and thereby, mobilise accounting as a factor hindering success: A lack of accounting information leads to missed entrepreneurial opportunities (Schafer 1990; Duan and Kinman 2000); poor accounting in small businesses is a barrier to export development (Leonidou, 2004); or the source of missed financing opportunities - with the implication of missed growth opportunities (Stanga and Tiller, 1983; Mitchell, Reid and Terry, 1995, 1997; Chittenden, Hutchinson and Hall, 1996; Berry, Grant and Jarvis, 2004). These studies were based mainly on large-scale surveys using postal questionnaire; their vision of 'success' was therefore narrow as, by necessity of the methodology, they isolated and focused on selected variables. They are therefore of limited help in understanding the complexities of small firms and entrepreneurial behaviour (Hlady-Rispal and Jouison-Laffitte, 2014) and the heterogeneous nature of the small business sector (Audretsch, 2012). The prevalent discourse of 'success' to be found in these studies is one which privileges neoliberal values of economic growth and increased employment to the detriment of the social and qualitative aspects of small business ownership. Hence there is a focus on identifying and lifting those 'barriers' to growth that are preventing small businesses becoming what they 'should' be.

Furthermore, this discourse of growth carries the implication that lifestyle (i.e. non-growth oriented) businesses are somehow lacking. Implicit to studies which link accounting with growth is the idea that there is a need to improve the quality of financial information or decision making in order to enable economic growth. Hence, such research is normative either in its inherent design or in the conclusions which are derived from exploratory findings. There is an implication underlying the rationale of such studies that small businesses could do better because poor accounting is hindering growth (Gul 1991; Leonidou 2004). 
The influence of neoliberal economics on small business accounting research: a critical evaluation of agendas and methodologies

Research is concerned with identifying what small businesses should be doing. This normative approach frequently involves exploring the imposition of large business accounting systems such as activity based costing (Jänkälä and Silvola 2012) or total quality management (Kober, Subraamanniam and Watson, 2012).

Linking accounting with growth is also found in the group of studies promoting small business growth models. In such studies, accounting is mobilised as an indicator of the stage of the firm's development (Churchill and Lewis, 1983; Robinson, Pierce, Vozikis and Mescon, 1984; Dodge and Robbins, 1992; Moores and Yuen, 2001; Hui-Hong and Tan, 2004; Davila, 2005). Although these studies yield some useful findings, a weakness in the use of growth models is that they presuppose a linear development of accounting linked to growth and a degree of uniformity in this process across different types of business.

There is a counter discourse found in a small number of studies which argue that small firm development is neither linear, nor best described by biological paradigms (Orser, HogarthScott and Riding, 2000), and that the presuppositions of growth models are misguided (Holmes, Kelly and Cunningham, 1991). Rather than treat the small firm as an autonomous entity that is separate from the owner-manager, these studies show that, with micro-firms in particular, a study of the business cannot be separated from a study of the owner-manager (O'Farrell and Hitchens, 1988; Boden, 1999; Ritchie and Richardson, 2000). Furthermore, many small business owner-managers have no growth orientation but rather are motivated by lifestyle factors (Fraser et al., 2015). This makes the assumptions surrounding growth models inappropriate for study of the majority of small businesses and particularly those classed as 'lifestyle' businesses. This counter discourse points to a need for more research which looks beyond narrow economic definitions of success.

\section{Accounting competency and growth}

The second category of SBAR studies look at the use of accounting information in small business decision-making. The concern of these studies is not so much the qualities of accounting information, but rather the degree of expertise with which it is used. The focus is therefore on the personal level of manager/owner-manager characteristics rather than the firm as an economic unit. The dominant discourse within this category mobilizes representations of entrepreneurship which produce an idealised neoliberal entrepreneurial subject position privileging innovation, creativity and growth orientation. Entrepreneurial qualities are valued primarily in terms of their contribution to economic growth. Studies looking at the management practices of small businesses have sought to establish a 
The influence of neoliberal economics on small business accounting research: a critical evaluation of agendas and methodologies

correlation between financial expertise and planning ability and growth of the firm (Cragg and King 1988; Seamon 1994; Maes, Sels and Roodhooft, 2005). For example, Lybaert (1998) found a positive link between the performance of small businesses and the use of accounting information. Orser et al. (2000) linked growth with the financial expertise and planning ability of the owner and found that the presence of a business plan was highly correlated with performance. Huang and Brown (1999) defined and classified problems faced by small businesses. Their classification shows that many problems could be alleviated by better use of accounting information. Joyce, Penlington and Woods (1997), Bridge (1998) and Rue and Ibrahim (1998) all found a positive connection between planning and performance. McChlery and Meechan (2000) looked at types of accounting information used by businesses in an attempt to benchmark financial management systems in small firms and understand why some are good and some are weak. Raymond and MagnenatThalman (1982), Holmes et al. (1991), Gul (1991), and Lybaert (1998), while not explicitly looking at management accounting, have looked at the relationship between business success and information systems. Information inadequacy is associated with business distress and failure (Storey, Keasey, Watson and Wynarczyk, 1987) and better information has been associated with success and survival (Jones, 1985) and business growth (Street and Meister, 2004; Davila, 2005). Although these studies cover a range of knowledge interests, all are complicit in maintaining a narrow focus on growth and the properties (good accounting information used well) which contribute towards growth. This focus, which is still prevalent (c.f. Zager, Sacer and Decman, 2012), serves to reinforce and reproduce the neoliberal discourse of entrepreneurship.

The small number of studies that offer a counter discourse suggest that non-economic concerns play an important role in the way owner-managers make their financial decisions (Greenbank, 1999) and may be more important than expected financial outcomes in determining overall attitude toward growth (Wiklund, Davidsson and Delmar, 2003). This counter discourse highlights the need for a more complex conceptualisation of rationality within decision making, one which allows for other norms and values (both economic and non-economic), as well as a wider range of goals than just profit maximisation (Curran, Jarvis, Kitchen and Lightfoot, 1997).

\section{Accounting services and growth}

The third area of research interest is the accounting services provided to small businesses by accountants or other business advisors and the manner in which these services can be improved (Lawson, 1995; Kirby and King, 1997; Duan and Kinman, 2000). The dominant 
The influence of neoliberal economics on small business accounting research: a critical evaluation of agendas and methodologies

discourse reflects the increased interest of banks in the small business sector as a result of the neoliberal economic agenda of the last 30 years. It also illustrates the instrumentality of research seeking 'quick-fix' solutions for lenders and finance providers to apply in their dealings with small businesses. The underlying presumption is that external advisors should encourage and support growth in small businesses by providing more useful accounting services (Kirby \& King, 1997; Gooderham, Tobiassen, Erik and Nordhaug, 2004) arising from a better understanding of the small business client and information needs (Barbera \& Hasso, 2013; Stone, 2011).

There is a counter discourse, not strongly expounded, but revealed within the conclusions of a small number of studies within this category. This suggests a need for a different type of research providing a better understanding of how accounting fits into the small business manager's world and of entrepreneurial behaviour in relation to accounting. For example, Marriott and Marriott (2000) undertook a qualitative study that aimed to determine the management information needs of small business owner-managers, the type and frequency of information preferred and the capacity of professional accountants to contribute to these needs. The authors concluded that there was considerable potential for the provision of accounting information, but that small business owners attribute low value to accounting information. The reasons for this cannot be understood without investigation of the meaning and values which small business managers attach to accounting and the issues and concepts that underpin accounting.

\section{Accounting regulation and growth}

The fourth theme relates to the impact of regulative burdens. The dominant discourse being that accounting regulation should not hinder small business growth implying that lower levels of regulation will stimulate growth; productive deregulation being a core theme of neoliberalism. The studies grouped within this theme examine a range of issues associated with regulative burdens to small businesses and hence, a barrier to growth. These include audit requirements (Collis et al., 2004; Collis, 2012), PAYE compliance (Chittenden, Kauser, Poutziouris and Sloan, 2005), reporting and filing requirements (Eierle, 2008), tax levels and VAT accounting requirements (Chittenden, Kauser and Poutziouris, 2003; Chittenden and Sloan, 2007). The focus is either on measuring the impact of regulation or establishing how the burden could be reduced. There are also attempts to identify positive tax incentives that stimulate growth (Chittenden, Oakey, Poutziouris and Michaelas, 2000; Sloan \& Chittenden, 2006). This range of interests is not surprising, as regulatory requirements represent the area of small business accounting most directly accessible in terms of policy making. For the 
The influence of neoliberal economics on small business accounting research: a critical evaluation of agendas and methodologies

researcher, this area provides the opportunity to offer policy-relevant recommendations. Policy makers relate to small businesses in terms of alleviation of financial reporting requirements (for example the FRSSE), VAT thresholds and audit requirements, fiscal measures such as R\&D tax credits and the Phoenix Fund.

Strong private sector growth is central to neoliberal economic policy and in the UK government policy in the last 30 years has increasingly incorporated interventions and business support policies designed to stimulate enterprise (Anyadike-Danes, Hart and Du, 2015). It is therefore of little surprise that studies sponsored by government funding agencies has resulted in research offering neat, easily implementable solutions to small business problems. These solutions have focused to a large extent on reducing burdens of accountability and regulation. The counter-discourse suggests that this approach may offer unfounded assumptions regarding the relationship between accountability and enterprise, and the notion that reduced regulation will somehow liberate small businesses. It also ignores the complexity of small business. Importantly, it is underpinned by a presumption that accountability is linked to internal accounting in small businesses in the same way as in larger businesses. This link has been questioned (Jarvis, Curran, Kitchen and Lightfoot, 2000; Collis and Jarvis, 2002). Furthermore, more recent research has challenged the 'red tape' perception of regulation, suggesting that it can be enabling as well as constraining and that a more nuanced understanding of small businesses' relationships with regulation is needed (Kitching, Hart and Wilson, 2015). All such factors point to a need for research that scrutinises the fluidity and complexity of accounting and management control within small firms.

\section{Discussion}

This study has revealed two features that dominate the SBAR research agenda. First, a concern with growth: how 'better' accounting can increase growth in individual businesses or increase the number of businesses that grow; and how to remove accounting related barriers to growth. The second feature is a normative approach, in terms of critiquing how small business accounting fails to measure up to some ideal or standard, usually derived from a large firm context.

\section{The concern with growth}

Growth has become a core theme of neoliberal small business economic policy. Gibb (2000b) speculates that the policy focus on growth businesses and the type of research which this produces may be a result of the influences of external stakeholders upon 
The influence of neoliberal economics on small business accounting research: a critical evaluation of agendas and methodologies

government. He suggests that 'there is no doubt that the venture capital companies, the banks, the major accounting firms, and the local authorities (in developing even more speculative incubator facilities) all nurture this particular typology of business' (Gibb, 2000b:26). However, there is a paradox to this focus. Although there is a rationale for such research in terms of the economic importance of small business growth, it has legitimised certain forms of 'worthy' enterprise as idealised policy subjects and in turn has marginalised alternative conceptions of entrepreneurship. In particular, non-growth-oriented or so called lifestyle businesses are marginalised in a neoliberal discourse of 'worthy' business enterprise that stresses economic growth. This marginalisation is unfortunate, as not only are lifestyle firms economically important in their own right, regardless of growth, but they are also markedly different to growth-oriented businesses. The economic importance of micro-firms (i.e. those with fewer than ten employees) is undeniable: within the broad category of small and medium sized enterprise (SME), micro-firms are by far the largest element. Of the 5.2 million private sector businesses in the UK, 3.3 million (62\%) are sole traders and $76 \%$ of all businesses are non-employers (BIS, 2014). Self-employment has been identified as a key driver in economic growth (BIS 2014). In the European Union, $92.4 \%$ of all businesses are micro-businesses and these account for $43 \%$ of all employment (European Commission, 2014). In the US, over 50\% of the working population work within small businesses and micro-businesses make up $75.3 \%$ of all private sector employers. (SBA, 2015)

This economic importance of micro-firms, coupled with the fact that many of their ownermanagers have no growth orientation (Fraser et al., 2015) means that a significant proportion of the business community is marginalised by a research agenda which is preoccupied with growth. There is also an important theoretical implication in that the focus on growth encourages an emphasis on the quantitative and economic to the detriment of the social and qualitative aspects of small business. This is despite the recognition that success for the small business cannot be simply equated with growth (Baron and Henry, 2011; Fisher, Maritz and Lobo, 2014); research has shown that small businesses pursue a range of goals other than growth (Jarvis et al., 2000) and these may change over time (Bellamy, Bowen and Simpson, 2003). There is also a methodological issue in equating success with growth when the aspirations of small business owners are not always growth related. Owner-managers have a variety of reasons for going into business and many actively avoid growth in favour of other lifestyle rewards (Jaouen and Lasch, 2015). This means that a research methodology which correlates accounting practices with performance measures such as increased turnover is inappropriate for examining non-growth lifestyle businesses. 
The influence of neoliberal economics on small business accounting research: a critical evaluation of agendas and methodologies

All of these factors point to the need for research which looks beyond narrow economic definitions of success to provide a better understanding of how small business owners particularly, lifestyle owners measure success. Within wider accounting research there is an interest in expanding accounting measures to encompass broader social and environmental factors. Small firms, particularly those that are free of the constraints of shareholder reporting may prove to be fertile ground for exploring alternative and broader accounting measures of success.

A additional theoretical implication is that linking accounting with growth leads to a perception of accounting as a functional means to an end. Accounting is generally seen as having a practical function of guiding decisions towards an increased economic efficiency. This narrow functional view of accounting in SBAR is at odds with developments in wider accounting research over the last 30 years, as indicated by the output of journals such as Accounting, Organizations and Society, Accounting, Auditing and Accountability Journal and Critical Perspectives on Accounting. As Anthony Hopwood commented in the first edition of Accounting, Organizations and Society, a functional view of accounting does not consider the social and organisational context within which accounting is produced. In particular, it is blind to the extent to which accounting defines or at least plays a role in the definition of the very ends it is trying to further (Hopwood, 1983). This criticism is particularly relevant within a micro-firm context where it is difficult to separate the person from the entity and therefore, personal from the business aspirations (Ritchie and Richardson, 2000). Accordingly, there is scope for more research which examines the social context of accounting in very small businesses. The unique closeness of the owner to business planning and control means that such businesses offer the potential for new and better understanding of the organisational context of accounting. Such research must be open to a broader perspective on measuring performance, as importantly, there is an aesthetic rationality to small business ownership which becomes invisible through a purely economic lens. The forms that such research might take are explored in the conclusions section of this article.

A preoccupation with growth has also led to a bias towards studying new firms, to the exclusion of those that have remained at the micro level for several years. A business still at the micro level after more than five years is ipso facto not a growth firm; however, focusing upon new firms does not necessarily tell us about older businesses. Research that has focused upon older small businesses underlines the importance of the differences between the two categories. For example, studies by McChlery and Meechan (2000) and McKinstry and Wallace (2004) identify important differences in the management accounting systems and financial practices of new and older small firms. This suggests that there is need for 
The influence of neoliberal economics on small business accounting research: a critical evaluation of agendas and methodologies

more research which looks at accounting within lifestyle businesses that have achieved long term survival success. There are a number of issues to be examined here; for example, a somewhat dated but widespread survey of small business owner-managers conducted by Gray, (1999) shows that $78 \%$ of 'life-style' owner-managers are reluctant to delegate. The neoliberal discourse problematizes this as something which needs to be 'fixed', as without delegation employment growth becomes difficult. However, for a lifestyle owner-manager, holistic control can be an important attraction of having one's own business (Parry, 2010). This in turn has implications for accounting needs. A lack of delegation negates the need for formalised and explicit management information and thereby, significantly influences the type of accounting routines used in small businesses (Parry, 2010). Furthermore, Gibb (2000b) points out that there is an assumption that businesses not growing in terms of turnover, profit or employment are not dynamic. In fact, it may be problems in dealing with dynamic situations which lead to a lack of growth; such firms might actually be in greater need of support. However, we need to understand what form that support should take. Gibb (2000b:26) suggests that 'steady state businesses or indeed survival businesses...cannot necessarily be associated with poor management'. As such, there is a need for research that does not originate from such presumptions.

The dominance of a normative approach

The second dominant feature of the studies examined in this article is their normative nature. This reflects the institutional infrastructure and ideological apparatus that legitimates the hegemony of neoliberal economics. Despite the trend to identify accounting practices in small businesses as a problem, some (c.f. McChlery and Meechan, 2000) have seen it as an opportunity to identify those accounting techniques and procedures which might best benefit small firms. A normative approach which benchmarks financial management systems enables the researcher to make recommendations about how advisors can step in and provide support to the business.

The normative approach to SBAR has led to a portrayal of the small firm (and its ownermanager) as lacking. From the studies in the sample, Nayak and Greenfield (1994) suggest that small businesses have little management information and poor control; Hankinson (1987) found small firm costing to be poor; Joyce et al. (1997) .identified poor formal strategic planning; Hall and Young (1991) and Keasey and Watson (1993) suggest that small business owners have poor financial management skills. Such conclusions are still found in more decent studies: Zager et al. (2012) suggest that accounting information is insufficiently used in decision-making processes and management of small firms, and Fraser et al. (2015) suggest that poor managerial skills may contribute to financing difficulties which 
The influence of neoliberal economics on small business accounting research: a critical evaluation of agendas and methodologies

restrict growth. This portrayal of the small business manager is at odds with other areas of small business literature, where the small business owner-manager is praised for entrepreneurial flair, creativity and major economic contribution (Calvo and Garcia, 2010; Wagener et al., 2010; Owens et al., 2013). There is therefore, an epistemological dissonance arising from this normative approach.

One of the greatest problems with normative studies is the mistake of treating the small firm simply as a scaled down version of a larger one. The reality is that the nature of small businesses in general - and the micro-firm in particular - is very different to their larger counterparts. The most important difference lies in the role and influence of the ownermanager; this is highlighted by Ritchie and Richardson (2000), who undertook a single firm case study analysing the social dynamics within the firm and the way these interacted with performance, monitoring, control and reporting. They suggested that it is "difficult to disentangle the person from any abstract entity which can be called 'the business'" (Ritchie and Richardson, 2000: 455). Such a realisation has profound implications for research methodology: The study of a micro-firm cannot be separated from a study of the ownermanager. This understanding is particularly important for SBAR if much of the control and planning of the business is tacit, informal and directed by the owner-manager in their day to day involvement in the business.

A research approach which starts with presuppositions about what constitutes good accounting practice blinds the researcher to the actual role played by accounting in the owner-managers' running of the business. A number of studies looking at small business growth have suggested that standard organisational theories do not fully grasp the implications of the differing attitudes to growth in small businesses for governance, accountability and enterprise (Wiklund et al., 2003; Tan, Menhoff and Chay, 2007; Navaretti, Castellani and Pieri, 2014). This would suggest that such prescriptive approaches to the subject cannot possibly succeed in revealing the real complexity of accounting in the small business.

It is clear that there are some practical methodological issues that lie behind the widespread preference for a normative approach to SBAR. A significant problem for the researcher looking at accounting in the micro-firm is identifying the subject of study. There are practical difficulties in identifying and accessing micro-firm accounting practices. Diversity in approaches to accounting and control is not easily captured through typical survey based methodologies (Parry, 2010). Daily control by the owner-manager and a lack of delegation found in micro-firms results in undocumented and informal systems and measures which are 
The influence of neoliberal economics on small business accounting research: a critical evaluation of agendas and methodologies

difficult for the researcher to capture (Jarvis et al, 2000). There is also a problem in establishing an appropriate measure of the impact of accounting on a business for which traditional measures such as increased turnover may not be valid (Bellamy et al, 2003). These problems have led to a suggestion from some researchers that internal accounting procedures in small businesses are not actually well enough defined or tangible enough to be a subject of study (Nayak and Greenfield, 1994; Mitchell and Reid, 2000; Kober et al., 2012). If this attitude is adopted, financial accounting, in the form of financial statements, becomes the only aspect of small business accounting that is available to study.

It may therefore, be suggested that it is this difficulty in identifying or measuring internal accounting procedures that has led researchers to a normative approach, one which attempts to address the question of what accounting procedures should be found in the small firm. Several of the studies covered in this review were critical of the small business owner-manager, finding fault in the lack of good practice as promoted by a management and accounting literature that is in turn based on large organisation practices (c.f. Storey et al., 1987; Holmes and Nicholls, 1989; Nayak and Greenfield, 1994; Kober et al., 2012; Jänkälä, and Silvola, 2012). Unfortunately, any attempt at a prescriptive answer, usually based upon the preconception that a small business is a scaled down version of a large business, comes up against the heterogeneity of small businesses and their managers (Birley and Westhead, 1990; Jarvis et al., 1996; Sullivan-Taylor and Branicki, 2011). This means that, as Jarvis et al. (2000:124) suggest: 'assuming a single, unambiguous model, which small firms should be admonished to follow or be judged by, is highly suspect.

\section{Conclusions}

This paper contributes to recent discussions on agendas and methodologies in small business research by identifying the research interests that constitute the body of SBAR published over the last 30 years. The study suggests that SBAR has been subject to the hegemony of a neoliberal economic ideology, the main manifestations of which have been a preoccupation with prescribing accounting strategies that produce positive economic growth consequences, and an universalisation and de-contextualisation of accounting techniques through a normative approach. This raises questions about the role and purpose of SBAR, the type of knowledge that it is trying to produce and therefore, the sorts of research questions and methodologies that should be applied. In particular, the study reveals that whilst much worthwhile research has been undertaken, some important areas of knowledge have been ignored. The comments in this concluding section focus on the two features of SBAR emerged as notable; a lack of theory building and a preoccupation with growth 
The influence of neoliberal economics on small business accounting research: a critical evaluation of agendas and methodologies

A need for more theory building

This article is not seeking to deny the importance of functional research. In fact, it could be argued that such research has increased in importance in recent years, in a climate in which researchers are being urged towards more engagement with and impact upon practitioners outside of academia. An important question for the small firm researcher is how impact translates for their discipline. The findings from this study would suggest that the main focus of impact for SBAR seems to be on practical guidance for policy makers and institutional stakeholders. This still leaves room for contributions in other areas, particularly that of theory building.

The under-theorisation of small business research has long been recognised (Gibb, 2000a; Perren, Berry and Blackburn, 2001), but the development of theory within SBAR faces a number of challenges. One is the fact that small business research and accounting research are often considered separate fields of study. Mainstream accounting research tends to be concerned with new technical developments and innovation (Baldvinsdottir, Mitchell and Nørreklit, 2010). On the other hand, the agenda driving small business research, as has been demonstrated here, is typically one of practical contribution to small business survival and growth in the form of policy development and business support. This has resulted in a tendency amongst researchers to draw upon mainstream accounting theory that has already been developed through the study of larger organisations, rather than the development of new theory specific to small business accounting.

A further reason for the under-theorisation of SBAR lies in the difficulty of accessing accounting in small businesses. Jarvis et al. (2000) point out that larger firms are more accessible to the researcher than small firms. This means that larger firm accounting practices have been more extensively examined and are better documented. This in turn has had a methodological impact on SBAR, in terms of 'an uncritical acceptance of a narrow view of large enterprise practices as the model to which small firms should aspire if they are to prosper (Jarvis et al., 2000:124). The result is that small business accounting studies have largely taken idealised (i.e. large business) practices as the basis for the propositions they seek to test. A challenge for future SBAR is to build theory that is distinctly small business in focus and which is differentiated from accounting theory developed in larger organisations.

The fact that accounting practices in small businesses are not well defined should not be a barrier to studying accounting with a view to theory development. Rather it should be seen as a prompt to change the approach if accounting in the micro-firm is largely tacit, then it is 
The influence of neoliberal economics on small business accounting research: a critical evaluation of agendas and methodologies

performative rather than substantive. It is about what managers do; it is about their meaning making and sense making within the context of their business activities. The small business, particularly the micro-business, should be seen as fertile ground for a move from normative research to research which seeks to increase our understanding of the relationship between accounting and the lived reality of the entrepreneur. If the small business is to be looked to as a source of creativity and innovation within a broader business context, then there is a risk that this creativity and innovation is being overlooked or even stifled by the imposition of normative accounting technologies. As such, the study of accounting within the small business context is ideally suited to a linguistic approach, as language is commensurate with meaning (Jones and Smith, 2014). Workplaces are recognised as sites of multiple, often contradictorily interests and narratives which are not easily reconciled. The small business offers a vehicle for developing understanding of how differing accounting narratives arise and establish performative hegemony as mechanism through which managers narrate a desired reality.

There is a need for a more complex conceptualisation of rationality within small business financial decision-making, one which allows for other norms and values (both economic and non-economic), as well as a range of goals that go wider than just profit maximisation. It is important to recognise that there is an aesthetic rationality to small business ownership which becomes invisible through a purely economic lens. There is need for a better understanding of how accounting fits into the small business manager's world and of entrepreneurial behaviour in relation to accounting. To this end, there are a number of bodies of existing research which could usefully inform future SBAR theory building and which would in turn benefit from a widening to a small business context.

One such area lies with those studies that have explored how accounting has different connotative meanings for different users, particularly as it is recognised that connotative meaning plays a role in shaping the perceptions and thoughts of those who are exposed to the information (Houghton, 1988; Tian and Zhou, 2015). A further useful parallel lies in research examining the use of accounting information in the not-for-profit sector. Such research has suggested that accounting-based performance measures can be counterproductive in the evaluation of charities (Arya and Mittendorf, 2015). The same argument can be applied to lifestyle businesses that are not profit and growth oriented. There is a need to identify appropriate measures that will not lead to dysfunctional decision making. 
The influence of neoliberal economics on small business accounting research: a critical evaluation of agendas and methodologies

In line with calls for entrepreneurship studies to adopt a more contextual approach (Spedale and Watson, 2014), an area of theory building needed within SBAR involves examining how accounting information shapes manager views of what constitutes organizational reality, and thereby determining the problems the firm chooses to address, and the range of possible actions it considers appropriate. The small business setting, where conventional and externally imposed accounting practices are often absent, offers fertile ground for such work.

In particular, the lifestyle micro-business offers an interesting opportunity for studying what Hopwood (1994) has termed 'vernacular accounting'; that is, accounting and information systems that are self-generated by managers and employees with a view to facilitating their work, rather than being part of a formal control system. Many micro-business ownermanagers have no formal accounting training and have little use for accounting information beyond that which meets their needs in the day to day running of the business. This is therefore, an ideal setting for exploring innovation, adaptability and flexibility in accounting and information systems, together with the impact on the firm's financial and strategic outcomes.

The lifestyle business that pursues a range of non-economic goals also offers an opportunity for further theory development around how accounting serves various purposes beyond its instrumental role in supporting rational decision making and, as such, may be seen as a socially constructed phenomenon that legitimizes organizations and expresses societal values (Ahrens and Chapman, 2007).

A need for a broader focus beyond growth

Even with research directed at policy and practice development there is a need for a wider focus away from just growth, and in particular to non-growth-oriented or so-called 'lifestyle' businesses. This paper has highlighted how an economically significant proportion of small firms are not growth-oriented. It is becoming more widely accepted that in fact only a relatively small proportion of small businesses are innovative, create new jobs and economic growth. Very few small firms achieve continuous growth and many fail early within their life (Storey, 2011). Statistics published by the Office for National Statistics show that more than $50 \%$ of new small businesses in the UK fail to survive longer than 5 years (ONS, 2014). This would suggest that the major issue is sustainability rather than growth and that a significant proportion of the business community is marginalised by a research agenda which is preoccupied with growth. This article therefore, calls for more research which focuses specifically on lifestyle businesses and addresses issues of sustainability rather than growth. 
The influence of neoliberal economics on small business accounting research: a critical evaluation of agendas and methodologies

Whereas in the broader entrepreneurial literature the small firm is praised for creativity and innovation and seen as a source of inspiration and ideas, when it comes to accounting the normative approach means that small businesses are seen as lacking and need 'fixing' with solutions drawn from larger businesses. To this extent, SBAR can be seen as being grounded in a modernist view that emphasises the importance of information and systems, and applies an instrumental logic. Furthermore, the neoliberal economic discourse problematizes the subjectivity of the entrepreneur as being at odds with how the entrepreneur is positioned in other small business and entrepreneurial literature. In particular, this subject positioning is at odds with the 'lifestyle' business that is not in pursuit of economic growth. The neoliberal ideals of globalisation of cultures, races, capital and products have perhaps lead to a homogenisation of the entrepreneurial identity that fits its ideals of economic growth, innovation and employment creation; a construction of the entrepreneur that Costa and Saraiva (2012:589) describe as "capitalist, Western, white, male, heterosexual and of European or North American origin". There is certainly a presumption of the convergence of individual and societal interests in small business workplace decisions, and that these interests are either purely or predominantly economic. This is at odds with entrepreneurial motivation research which has shown a much wider range of goals and ambitions within small businesses, particularly when it comes lifestyle businesses.

Entrepreneurial success is now being recognised as going beyond the organisational economic level to include personal, social and health issues of the individual (Baron and Henry, 2011; Fisher et al., 2014). SBAR therefore, needs to move to a conceptualisation of success that encompasses the personal and aesthetic rationality of the lifestyle business. There is a need for a different epistemological perspective and methodology, particularly for researching those 'lifestyle' micro-firms that constitute a major part of the economy. Such a perspective needs to be sensitive to the close personal involvement of the owner-manager, the range of objectives and definitions of success in lifestyle businesses, the informal, often tacit nature of accounting in such an environment and the impact of external influences. Despite the economic significance of micro-firms, the frequent lack of growth orientation means that such businesses are alienated or simply ignored by most SBAR. The neoliberal discourse which dominates the research agenda has created a hegemony of certain forms of worthy enterprise which has eclipsed lifestyle micro-firms.

Finally, that body of work that has examined the role of external accountants and advisors would be usefully expanded by more work examining the process of communication between the external preparers of accounting information and the small business users. Such research could focus on how meaning is established and shared between parties. 
The influence of neoliberal economics on small business accounting research: a critical evaluation of agendas and methodologies

Study limitations

The conclusions drawn above are based on a sample of 108 academic papers, the selection of which was shaped by both the data bases used and the definition of what constitutes SBAR. It is possible that the selection method may have led to a bias towards certain types of research and certain research interests. A different definition may, for example, have encompassed more studies which offered stronger counter-discourses. Furthermore, the sample, although encompassing studies from across the globe, has a Euro-centricity. However, the fact that the sample included papers from 27 different leading academic journals provides assurance that the range of research interests covered is a reasonable representation of the interests of small business accounting researchers. Future reviews of SBAR may focus more strongly on papers published in America or Asia in order to confirm whether patterns of research interests are the same.

\section{References}

Ahrens, T. and C. Chapman, C. (2007) 'Management accounting as practice'. Accounting, Organizations and Society, 32, pp. 1-27

Anyadike-Danes, M., Hart, M. and Du, J. (2015) 'Firm dynamics and job creation in the United Kingdom: 1998-2013', International Small Business Journal, 33(1), pp.12-27.

Arya, A. \& Mittendorf, B. (2015) 'Career concerns and accounting performance measures in nonprofit organizations'. Accounting, Organizations and Society, 40, pp.1-12.

Audretsch, D. (2012),"Entrepreneurship research", Management Decision, 50(5), pp. 755 764

Audretsch, D.B. and Keilbach, M. (2006) 'Entrepreneurship, Growth and Restructuring', in Mark Casson, Bernard Yeung, Anuradha Basu and Nigel Wadeson (eds) The Oxford Handbook of Entrepreneurship, pp. 281-310. Oxford: Oxford University Press.

Baldvinsdottir, G., Mitchell, F. and Nørreklit, H. (2010). "Issues in the relationship between theory and practice in management accounting." Management Accounting Research 21(2), pp. 79-82.

Barbera, F. and Hasso, T. (2013) 'Do We Need to Use an Accountant? The Sales Growth and Survival Benefits to Family SMEs', Family Business Review, 26(3) pp.271-292.

Baron, R. A. and Henry, R. A. (2011), "Entrepreneurship: The genesis of organizations" in Zedeck, Sheldon (ed) APA Handbook of Industrial and Organizational Psychology Vol 1: Building and Developing the Organization, Washington: American Psychological Association, pp. 241-273.

Bellamy, S., Bowen, F.E. and Simpson, M. (2003) 'Small business success factors: an owners' perspective'. Paper presented to the $26^{\text {th }}$ Institute of Small Business Affairs conference: SMEs in the Knowledge Economy.

Berry, A., Grant, P. and Jarvis, R. (2004) 'European bank lending to the UK SME sector: an investigation of approaches adopted'. International Small Business Journal. 22(2), pp. 115-131.

Birley, S. and Westhead, P. (1990) 'Growth and Performance Contrasts between 'Types' of Small Firm', Strategic Management Journal. 11, pp. 535-557.

BIS (2014) Business population estimates for the UK and Regions 2014. Department for Business, Innovation and Skills. Statistical Release URN 14/92. October 
Blackburn, R. and Kovalainen, A. (2009) 'Researching small firms and entrepreneurship: Past, present and future', International Journal of Management Reviews, 11(2), pp.127148.

Blackburn, R. and Smallbone, D. (2008) 'Researching Small Firms and Entrepreneurship in the UK: Developments and Distinctiveness', Entrepreneurship Theory and Practice, 32(2), pp. 267-288.

Boden, R. (1999) "Figure it out yourself: financial reporting, accounting and the selfemployed', Critical Perspectives on Accounting. 10, pp. 37-62.

Bridge, J. (1998) 'How planning and Capital Budgeting Improve SME Performance', Long Range Planning. 31(6), pp. 848-857.

Burchell, S., Clubb, C., Hopwood, A., J. Hughes, J. \& Nahapiet. J. (1980) 'The roles of accounting in organizations and society'. Accounting, Organizations and Society, 5, pp. $5-27$.

Calvo, J.C.A. and Garcia, G.M. (2010) 'Established Business Owners' Success: Influencing Factors', Journal of Developmental Entrepreneurship, 15(3). pp. 263-286.

Chittenden, F., Oakey, R., Poutziouris P. and Michaelas N. (2000) "Taxation and the Performance of Technology-based Small Firms." Small Business Economics 14(1): pp.11-36.

Chittenden, F., Kauser, S. and Poutziouris P. (2003) "The impact of tax regulation on small business in the UK, USA, Australia and New Zealand." International Small Business Journal 21, pp 93-115.

Chittenden, F. and Sloan, B. (2007) "Quantifying Inequity in the Taxation of Individuals and Small Firms." British Tax Review, 1, pp.58-72.

Chittenden, F., Hutchinson P. and Hall G. (1996) "Small Firm Growth, Access to Capital Markets and Financial Structure: review of issues and empirical investigation." Small Business Economics, 8(1): pp.59-67.

Chittenden, F., Kauser, S., Poutziouris P. and Sloan B. (2005) "The Regulatory Burdens of Small Firms in the EU, USA and UK." Wirtschaftspolitische Blätter 10, no. 2, pp 230244.

Churchill, N.C. and Lewis, V.L. (1983) 'The five stages of small business growth' Harvard Business Review. May-June pp. 30-50.

Collis, J. (2012) 'Determinants of voluntary audit and voluntary full accounts in micro- and non-micro small companies in the UK'. Accounting and Business Research, 42(4) pp. 441-468.

Collis, J. and Jarvis, R. (2002) 'Financial Information and the Management of Small Private Companies', Journal of Small Business and Enterprise. 9(2), pp. 100-110.

Collis, J., Jarvis, R. and Skerratt, L. (2004) 'The demand for the audit in small companies in the UK'. Accounting and Business Research, 34(2), pp. 87-101.

Costa, A M. da. and Saraiva, L.A.S. (2012). "Hegemonic discourses on entrepreneurship as an ideological mechanism for the reproduction of capital." Organization 19(5), pp. 587614.

Cragg, P. and King, M. (1988) 'Organizational Characteristics and Small Firms' Performance Revisited', Entrepreneurship Theory and Practice. Winter, pp. 49-64.

Cunningham L.X. (2011) "SMEs as motor of growth: A review of China's SMEs development in thirty years (1978-2008)" Human Systems Management 30, pp. 39-54.

Curran, J. and Blackburn, R.A. (2001) Researching the Small Enterprise. London: Sage.

Curran, J., Jarvis, R., Kitchen, J. and Lightfoot, G. (1997) 'The Pricing Decision in Small Firms: Complexities and the Deprioritising of Economic Determinants', International Small Business Journal. 15(2), pp. 17-32.

Dannreuther, C. (2009), 'The political economy of entrepreneurship,' International Small Business Journal, 27(1-2), 522-524.

Davila, T. (2005) 'An exploratory study on the emergence of management control systems: formalizing human resources in small growing firms'. Accounting, Organizations and Society. 30(3), pp. 222-248. 
Dodge, H. R. and Robbins, J.E. (1992) 'An Empirical Investigation of the Organisational Life Cycle Model for Small Business Development and Survival', Journal of Small Business Management. 30(1), pp. 27-37.

Duan, Y. and Kinman, R. (2000) 'Small manufacturing businesses: Meeting decision support needs', Journal of Small Business and Enterprise Development. 7(3), pp. 272-283.

Eierle, B. (2008) "Filing Practice of Small and Medium-sized Companies". International Small Business Journal. 26(4), pp.491-528.

European Commission (2014) Annual Report on European SMEs 2013/2014. European Commission Publications Office, 345/PP/ENT/CIP/13/F/N02C031.

Ezzamel, M and Bourn, M. (1990) 'The Roles of Accounting Information Systems in an Organisation Experiencing Financial Crisis' Accounting, Organizations and Society. 15(5), pp. 399-429.

Fisher, R., Maritz, A. and Lobo, A. (2014) "Evaluating entrepreneurs' perception of success: development of a measurement scale", International Journal of Entrepreneurial Behaviour and Research, 20(5), (Earlycite)

Fraser, S., Bhaumik, S.K. and Wright, M. (2015) 'What do we know about entrepreneurial finance and its relationship with growth?' International Small Business Journal, 33(1), pp. 70-88.

Garud, R., Hardy, C. and Maguire, S. (2007) 'Institutional Entrepreneurship as Embedded Agency: An Introduction to the Special Issue', Organizational Studies 28(7): 957-69.

Gibb, A. (2000a). Small and medium enterprise development: borrowing from elsewhere? A research and development agenda. Journal of Small Business and Enterprise Development, 7(3), pp. 199-211.

Gibb, A. (2000b) 'SME Policy, Academic Research and the Growth of Ignorance, Mythical Concepts, Myths, Assumptions, Rituals and Confusions'. International Small Business Journal. 18(3), pp. 13-34.

Gioia, D.A., Price, K.N., Hamilton, A.L. and Thomas, J.B. (2010) 'Forging an Identity: An Insider-outsider Study of Processes Involved in the Formation of Organizational Identity'. Administrative Science Quarterly, 55, pp.1-46.

Gooderham, P.N., Tobiassen, A., Erik, D. and Nordhaug, O. (2004) 'Accountants as sources of business advice for small firms'. International Small Business Journal. Vol. 22(1), pp. 5-23.

González-Loureiro, M. and Pita-Castelo, J. (2012) "A model for assessing the contribution of innovative SMEs to economic growth: The intangible approach". Economics Letters, 116(3), pp. 312-315.

Gray, C. (1999) 'Stages of Growth and Entrepreneurial Growth Career Motivation', Working Paper Series, Small and Medium Enterprise Research Unit, The Open University Business School, 99/1SMERU.

Greenbank, P. (1999) 'The Pricing Decision in the Micro-Business: A Study of Accountants, Builders and Printers', International Small Business Journal. Vol. 17(3), pp. 60-74.

Gul, F.A. (1991) 'The effects of management accounting systems and environmental uncertainty in small business manager's performance.' Accounting and Business Research. 22(85), pp. 57-81

Hall, G. and Young, B. (1991) 'Factors Associated with Insolvency Amongst Small Firms', International Small Business Journal. 9(2), pp. 54-63.

Hankinson, A. (1987) 'Small Firms' Pricing - The Neglected Art', International Small Business Journal. 5(4), pp. 34-44.

Hlady-Rispal, M. and Jouison-Laffitte, E. (2014) 'Qualitative Research Methods and

Epistemological Frameworks: A Review of Publication Trends in Entrepreneurship'. Journal

of Small Business Management, 52(4), pp. 594-614.

Holmes, S. and Nicholls, D. (1989) 'Modelling the accounting information requirements of small businesses', Accounting and Business Research. 19(74), pp. 143-150.

Holmes, S., Kelly, G. and Cunningham, R. (1991) 'The small firm information cycle: a reappraisal', International Small Business Journal. 9(2), pp. 41-53. 
Hopwood, A.G. (1983) 'On Trying to Study Accounting in the Contexts in which it Operates', Accounting, Organizations and Society. 8, pp. 287-305.

Hopwood, A.G. (1994) Fashionable facades and vernacular accountings: Reflections on some current developments in management accounting. University of Edinburgh. Public lecture.

Houghton, K.A. (1988) 'The measurement of meaning in accounting: A critical analysis of the principle evidence'. Accounting, Organizations and Society, 13, pp. 263-280.

Howard, R. (1990) 'Can Small Businesses Help Countries Compete?', Harvard Business Review. 68(6), pp. 89-103.

Huang, X. and Brown, A. (1999) 'An Analysis and Classification of Problems in Small Businesses', International Small Business Journal. 18(1), pp. 73-84.

Hui-Hong, J.K.L. and Tan, K.H. (2004) 'SME's business growth model: a medium to big effort'. International Journal of Management and Enterprise Development. 1(3), pp. 112.

Jänkälä, S. and Silvola, H. (2012) "Lagging Effects of the Use of Activity-Based Costing on the Financial Performance of Small Firms", Journal of Small Business Management. 50(3), pp.498-523.

Jaouen, A. and Lasch, F. (2015) 'A new typology of micro-firm owner-managers', International Small Business Journal, 33(4), pp. 397-421.

Jarvis, R., Curran, J., Kitching, J. and Lightfoot, G. (1996) The Financial Management of Small Firms: An Alternative Perspective. The Chartered Association of Certified Accountants, Research Report No. 49. London: Certified Accountants Educational Trust.

Jarvis, R., Curran, J., Kitching, J. and Lightfoot, G. (2000) 'The use of quantitative and qualitative criteria in the measurement of performance in small firms', Journal of Small Business and Enterprise Development. 7(2), pp. 123-133.

Jones, C.S. (1985) 'An empirical study of the evidence for contingency theories of management accounting systems in conditions of rapid change', Accounting, Organizations and Society. 10, pp. 303-328.

Jones, M. and Smith, M. (2014) 'Traditional and alternative methods of measuring the understandability of accounting narratives'. Accounting, Auditing \& Accountability Journal. 27(1), pp. 183-208.

Joyce, P., Penlington, S. and Woods, A. (1997) 'Strategic Management Styles in Small Firms: A replication study', paper presented to $20^{\text {th }}$ ISBA National Small Firms Policy and Research Conference, Belfast.

Keasey, K. and Watson, R. (1993) Small Firm Management, Ownership, Finance and Performance. Oxford: Blackwell

Khan, F.R., Munir, K.A. and Willmott, H. (2007) 'A Dark Side of Institutional Entrepreneurship Soccer Balls, Child Labour and Postcolonial Impoverishment', Organization Studies 28(7): pp. 1055-77.

Kirby, D.A. and King, S.H. (1997) 'Accountants and Small Firm Development: Filling the Expectation Gap', Service Industries Journal. 17(2), pp. 294-304.

Kitching, J., Hart, M. and Wilson, N. (2015) 'Burden or benefit? Regulation as a dynamic influence on small business performance'. International Small Business Journal, 33(2), pp. 130-147.

Kober, R., Subraamanniam, T. and Watson, J. (2012) "The impact of total quality management adoption on small and medium enterprises' financial performance", Accounting \& Finance. 52(2), pp.421-438.

Koryak, O., Mole, K.F., Lockett, A., Hayton, J.C., Ucbasaran, D. and Hodgkinson, G.P. (2015) 'Entrepreneurial leadership, capabilities and firm growth', International Small Business Journal, 33(1), pp. 89-105.

Lawson, R. (1995) The Attitude of the Accountancy Profession to SMEs. London: ICAEW.

Lechner, C. and Gudmundsson, S.V. (2014) 'Entrepreneurial orientation, firm strategy and small firm performance'. International Small Business Journal, 32(1), pp. 36-60. 
Leonidou, L.C. (2004) 'An analysis of the barriers hindering small business export development'. Journal of Small Business Management, 42(3), pp.279-303.

Lumpkin, T. and Dess, G. (1996) 'Clarifying the Entrepreneurial Orientation Construct and Linking it to Performance', Academy of Management Review 21(1): pp.135-72.

Lybaert, N. (1998) 'The information use in an SME: its importance and some elements of influence', Small Business Economics. 10(2), pp. 171-191.

Maes, J., Sels, L. and Roodhooft, F. (2005) 'Modelling the Link between Management Practices and Financial Performance: Evidence from Small Construction Companies'. Small Business Economics. 25, pp. 17-34.

Marriott, N. and Marriott, P. (2000) 'Professional accountants and the development of a management accounting service for the small firm: barriers and possibilities', Management Accounting Research. 11, pp. 475-492.

McChlery, S. and Meechan, L. (2000) 'Barriers and Catalysts to Financial Management Systems in Small Sized Enterprises', Conference proceedings of 23rd ISBA National Small Firms Policy and Research Conference. Aberdeen.

McKinstry, S. and Wallace, K. (2004) 'Cullen, Lochhead and Brown, architects: the business, financial and accounting history of a non-profit maximising firm, 1902-2002'. Accounting, Business and Financial History. 14(1), pp. 183-207.

McMahon, R.G.P. (2001) 'Business Growth and Performance and the Financial Reporting Practices of Australian Manufacturing SMEs', Journal of Small Business Management. 39(2), pp. 152-164.

McMahon, R.G.P. and Davies, L.G. (1991) 'Financial reporting and analysis in smaller growth enterprises: evidence on practice in the North-East of England', Accounting and Finance Research Paper 4/91, The Flinders University of South Australia.

Mitchell, F. and Reid, G.C (2000) 'Problems, challenges and opportunities: the small business as a setting for management accounting research'. Management Accounting Research, 11(4), pp. 385-390.

Mitchell, F., Reid, G.C. and Terry, N.G. (1995) 'Post Investment Demand for Accounting Information by Venture Capitalists', Accounting \& Business Research. 25(99), p186-196.

Mitchell, F., Reid, G.C. and Terry, N.G. (1997) 'Venture capital supply and accounting information system development', Entrepreneurship: Theory and Practice. Vol. 21(4), pp. 45-63.

Moores, K. and Yuen, S. (2001) 'Management Accounting Systems and Organisational Configuration: A Life-Cycle Perspective', Accounting, Organizations and Society. 26, pp. 351-389.

Moreno, A.M. and Casillas, J.C. (2008) 'Entrepreneurial orientation and growth of SMEs: A causal model'. Entrepreneurship Theory and Practice, 32(3), pp. 507-528.

Navaretti, G.B., Castellani, D. and Pieri, F. (2014) 'Age and firm growth: evidence from three European countries', Small Business Economics, 43, pp. 823-837.

Nayak, A. and Greenfield, S. (1994) 'The Use of Management Accounting Information for Managing Micro Businesses' in A. Hughes and D.J. Storey (eds.) Finance and The Small Firm. London: Routledge.

Nightingale, P. and Coad, A. (2014) "Muppets and gazelles: political and methodological biases in entrepreneurship research", Industrial and Corporate Change, V23(1), pp. 113-143.

O'Farrell, P.N. and Hitchins, D.W.N. (1988) 'Alternative theories of small-firm growth: A critical review', Environment and Planning. 20. pp. 1365-1382.

Ogbor, J.O. (2000) "Mythicizing and Reification in Entrepreneurial Discourse: IdeologyCritique of Entrepreneurial Studies" Journal of Management Studies 37:5, pp. 605-635.

ONS (2014) Business Demography, 2013. Statistical Bulletin published 27 November, 2014, Office for National Statistics.

Orser, B.J., Hogarth-Scott, S. and Riding, A.L. (2000) 'Performance, Firm Size, and Management Problem Solving', Journal of Small Business Management. 38(4), pp. 129146. 
Owens, K.S., Kirwan, J.R., Lounsbury, J.W, Levy, J.J. and Gibson, L.W. (2013) 'Personality correlates of self-employed small business owners' success', Work, 45, pp. 73-85.

Parker, S.C. (2006) 'Entrepreneurship, Self-Employment and the Labour Market', in Mark Casson, Bernard Yeung, Anuradha Basu and Nigel Wadeson (eds) The Oxford Handbook of Entrepreneurship, pp. 435-60. Oxford: Oxford University Press.

Parry, S.N. (2010) 'Smalltalk: Rhetoric of control as a barrier to growth in artisan microfirms'. International Small Business Journal. 28(4), pp. 378-397.

Perren, L., Berry, A. and Blackburn, R. (2001) 'The UK small business research community and its publication channels: Perceptions and ratings', Journal of Small Business and Enterprise Development, 8(1), pp. 76-90.

Perren, L. and Jennings, P. (2012) 'Discursive and Narrative perspectives of Entrepreneurship and Small Business: A Systematic literature Review' International Small Business Journal (Virtual special issue). ISSN 0266-2426

Pompe, P. and BilderBeek, J. (2004) 'The prediction of bankruptcy of small- and mediumsized industrial firms'. Journal of Business Venturing. 20(6), pp. 847-868.

Raymond, L. and Magnenat-Thalman, N. (1982) 'Information systems and small businesses: are they used in managerial decisions', American Journal of Small Business. 6(4), pp. 20-26.

Reid, G.C. (1995) 'Early life-cycle behaviour of micro-firms in Scotland', Small Business Economics. 7, pp. 89-95.

Ritchie, J. and Richardson, S. (2000) 'Smaller Business Governance: Exploring Accountability and Enterprise from the Margins, Management Accounting Research. 11, pp. $451-474$

Robinson, R.B., Pearce, J.A., Vozikis, G.S. and Mescon, T.S. (1984) 'The Relationship Between Stage of Development and Small Firm Planning and Performance', Journal of Small Business Management. 22 (April), pp. 45-52.

Romano, C.A and Ratnatunga, J (1994) 'Growth stages of small manufacturing firms: the relationship with planning and control', Public Policy. 13(1) pp. 173-195.

Rue, L.W. and Ibrahim, N.A. (1998) 'The Relationship between planning Sophistication and Performance in Small Businesses', Journal of Small Business Management. 36(4), pp. 24-33.

Runyan, R., Droge, C. and Swinney, J. (2008) "Entrepreneurial Orientation versus Small Business Orientation: What are their relationship to firm performance?", Journal of Small Business Management, 46(4), pp. 567-588.

SBA (The US Small Business Administration) (2015) Small Business Facts. Available at www.sba.gov.

Schafer, D.S. (1990) 'Level of Entrepreneurship and Scanning Source Usage in Very Small Businesses', Entrepreneurship Theory and Practice. 15(4), pp. 19-31.

Seamon, P. (1994) 'An Analysis of the Determination of Self-Employment Status and Earnings', discussion paper, Department of Economics, University of Aberdeen.

Short, J.C., Ketchen, D.J., Shook, C.L. and Ireland, R.D. (2010) 'The Concept of "'Opportunity"' in Entrepreneurship Research: Past Accomplishments and Future Challenges', Journal of Management 36(1), pp.40-65.

Sloan B, and Chittenden F. (2006) 'Fiscal policy and self-employment: targeting business growth' Environment and Planning C: Government and Policy, 24(1), pp.83 - 98.

Smallbone, D., Leigh, R. and North, D. (1995) 'The characteristics and strategies of high growth SMEs', International Journal of Entrepreneurial Behaviour \& Research. 1(3).

Smith, D. (1997) 'Small is beautiful, but difficult: towards cost effective research for small businesses'. Journal of the Market Research Society. 39(1), pp. 273-291.

Spedale, S. and Watson, T.J. (20014) 'The emergence of entrepreneurial action: At the crossroads between institutional logics and individual life-orientation' International Small Business Journal, 32(7), pp. 759-776.

Stanga, K. and Tiller, M. (1983) "Needs of Loan Officers for Accounting Information from Large versus Small Companies". Accounting \& Business Research, 14(53), pp.63-70. 
Stone, G. (2011) 'Let's talk: Adapting accountants' communications to small business managers' objectives and preferences', Accounting, Auditing \& Accountability Journal, 24(6), pp.781-809.

Storey, D.J. (2006), 'Evaluating SME policies and programmes: Technical and political dimensions,' in M. Casson, B. Yeung, A. Basu and N. Wadeson (eds), The Oxford Handbook of Entrepreneurship. Oxford University Press: Oxford, UK, pp. 248-278.

Storey, D.J. (2011) 'Optimism and chance: The elephants in the entrepreneurship room'. International Small Business Journal, 29(4), pp. 303-321.

Storey, D., Keasey, K., Watson, R. and Wynarczyk, P. (1987) The Performance of Small Firms. Beckenham, Kent: Croon Helm Ltd.

Strauss, A., and Corbin, J. (1998) Basics of Qualitative Research: Techniques and Procedures for Developing Grounded Theory, 2d ed. Thousand Oaks, CA: Sage

Street, C.T. and Meister, D.B. (2004) 'Small Business Growth and Internal Transparency: The Role of Information Systems'. MIS Quarterly. 28(3), pp. 473-506.

Sullivan-Taylor, B. and Branicki, L. (2011) 'Creating resilient SMEs: why one size might not fit all'. International Journal of Production Research, 49(18), pp. 5565-5579.

Tan, W.L., Menkhoff, T. and Chay, Y.W. (2007) 'The effects of entrepreneurial growth orientation on organisational change and form growth'. Small Enterprise Research, 15(2), pp. 88-99.

Thomas, J. and Evanson, R.V. (1987) 'An Empirical Investigation of Association between Financial Ratio Use and Small Business Success', Journal of Business Finance and Accounting. Vol. (December), pp. 555-571.

Thorpe, R., Holt, R., MacPherson, A. and Pittaway, L. (2005) 'Using knowledge within small and medium-sized firms: A systematic review of the evidence.' International Journal of management Reviews, 7(4), pp. 257-281.

Tian, Y. and Zhou, H. (2015) 'From bottom line to consumers' mind: The framing effects of accounting information'. Accounting, Organizations and Society, 43, pp. 56-66.

Tranfield, D., Denyer, D. and Smart, P. (2003) 'Towards a methodology for developing evidence-informed management knowledge by means of systematic review.' British Journal of Management, 14(3), pp. 207-222.

Varum, C. and Rocha, V. (2013) "Employment and SMEs during crises". Small Business Economics, 40(1), pp. 9-25.

Volery, T. and Mazzarol, T. (2015) 'The evolution of the small business and entrepreneurship field: A bibliometric investigation of articles published in the International Small Business Journal' International Small Business Journal, 33(4), pp. 374-396.

Wagener, S., Gorgievski, M. and Rijsdijk, S. (2010) 'Businessman or host? Individual differences between entrepreneurs and small business owners in the hospitality industry', The Service Industries Journal, 30(9), pp. 1513-1527.

Wales, W., Wiklund, J. and McKelvie, A. (2015) 'What about new entry? Examining the theorized role of new entry in the entrepreneurial orientation-performance relationship'. International Small Business Journal, 33(4), pp. 351-373.

Watkins, D.D. (1995) 'Changes in the Nature of UK Small Business Research, 1980-1990. Part Two: Changes in the Nature of Output', Small Business and Enterprise Development. 2(1), pp. 59-66.

Wiklund, J., Davidsson, P. and Delmar, F. (2003) 'What do they think and feel about growth? An expectancy-value approach to small business manager's attitude towards growth', Entrepreneurship: Theory and Practice. Vol. 27(3), pp. 247-271.

Zager, K., Sacer, I.M. and Decman, N. (2012) 'Financial ratios as an evaluation instrument of business quality in small and medium-sized enterprises'. International Journal of Management Cases, 14(4), pp. 373-385. 
Table 1: Frequency of papers by Journal Source

\begin{tabular}{|lr|}
\hline Journal & Freq. \\
\hline International Small Business Journal & 20 \\
Journal of Small Business Management & 16 \\
Accounting and Business Research & 11 \\
Journal of Small Business and Enterprise Development & 9 \\
Small Business Economics & 8 \\
Environment and Planning C: Government and Policy & 6 \\
Entrepreneurship Theory and Practice & 6 \\
Small Enterprise Research & 5 \\
Management Accounting Review & 4 \\
Accounting, Organizations and Society & 3 \\
British Accounting Review & 2 \\
Qualitative Research in Accounting \& Management & 2 \\
Strategic Management Journal & 2 \\
Other Academic Journals (frequency of 1) & 14 \\
Total & $\mathbf{1 0 8}$ \\
\hline
\end{tabular}

